Liquid Motion Experiment Flight Test Results

David J. Chato and Penni J. Dalton

Lewis Research Center, Cleveland, Ohio

Franklin T. Dodge and Steve Green

South West Research Institute, San Antonio, Texas

Prepared for the 34th Joint Propulsion Conference

cosponsored by AIAA, ASME, SAE, and ASEE

Cleveland, Ohio, July 12-15, 1998

National Aeronautics and

Space Administration

Lewis Research Center 
Available from

NASA Center for Aerospace Information 7121 Standard Drive Hanover, MD 21076

Price Code: A03

National Technical Information Service 5287 Port Royal Road Springfield, VA 22100 Price Code: A03 


\title{
LIQUID MOTION EXPERIMENT FLIGHT TEST RESULTS
}

\author{
David J. Chato and Penni J. Dalton \\ National Aeronautics and Space Adminsitration \\ Lewis Research Center \\ Cleveland, Ohio, 44135 \\ Franklin T. Dodge and Steve Green \\ South West Research Institute \\ P.O. Drawer 28510 \\ San Antonio, TX, 78228
}

\begin{abstract}
The Liquid Motion Experiment (LME), designed to study the effects of liquid motion in rotating tanks, was flown on STS 84. LME was essentially a spin table that created a realistic nutation motion of scale-model tanks containing liquid. Two spherical and two cylindrical transparent tanks were tested simultaneously, and three sets of such tanks were employed to vary liquid viscosity, fill level, and propellant management device (PMD) design. All the tanks were approximately $4.5 \mathrm{in}$. diameter. The primary test measurements were the radial and tangential torques exerted on the tanks by the liquid. Resonant frequencies and damping of the liquid oscillations were determined by sine sweep tests. For a given tank shape, the resonant frequency depended on fill level. For the cylindrical tanks, the resonances had somewhat different frequencies for the tangential axis $(0.55$ to 0.75 times spin rate) and the radial axis ( 0.73 to 0.78 times spin rate), and the tangential axis resonance agreed more closely with available analytical models. For the spherical tanks, the resonant frequencies were between 0.74 to 0.77 times the spin rate and were the same for the tangential and radial axes. The damping coefficients varied from about 1 to 3 percent of critical, depending on tank shape, fill level, and liquid viscosity. The viscous energy dissipation rates of the liquid oscillations were determined from sine dwell tests. The LME energy dissipation rates varied from 0.3 to 0.5 times the estimates obtained from scaling previous ground tests and spacecraft flight data. The PMDs sometimes enhanced the resonances and energy dissipation rates and sometimes decreased them, which points out the need to understand better the effects of PMD on liquid motion as a function of PMD and tank design.
\end{abstract}

\section{Nomenclature}

d tank diameter

"This paper is declared a work of the U.S. Government and is not subject to copyright protection in the United States."

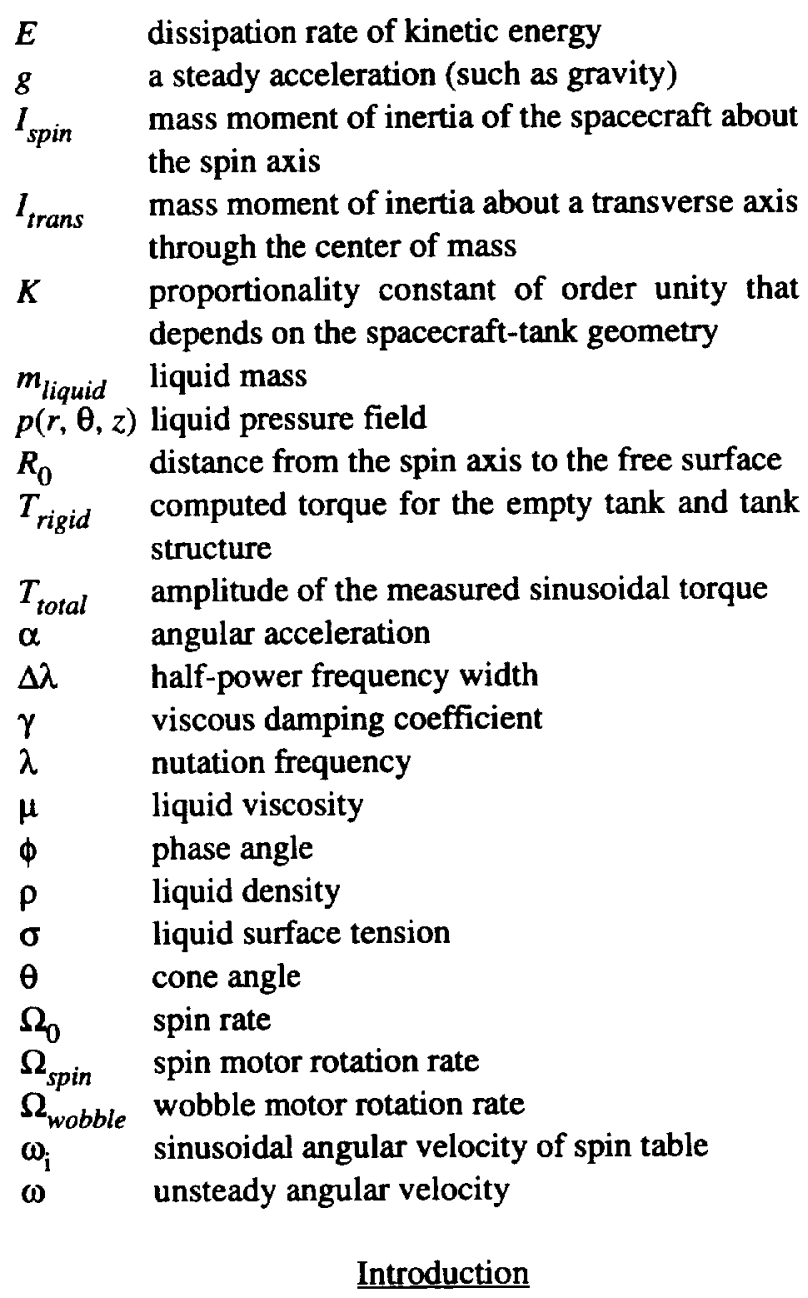

Background

The Liquid Motion Experiment (LME) is a flight investigation of the characteristics of liquid motions in spinning, nutating tanks. The data from the flight tests will aid in determining the effects of such motions on the stability of spinning spacecraft. 
Spacecraft are made to spin for a number of reasons, including gyroscopic stiffness, equal distribution of solar thermal loads, and positioning of the liquids in a tank over the outlet. Just as for any freely-spinning body, a spinning spacecraft can have a nutation motion superimposed on its steady spin; this nutation is sometimes called "coning." During nutation, the spin axis of a spacecraft rotates around its angular momentum vector, which is fixed in inertial space in the absence of any external torques or forces. Figure 1 illustrates such a motion for an idealized spacecraft containing liquid in two off-axis tanks.

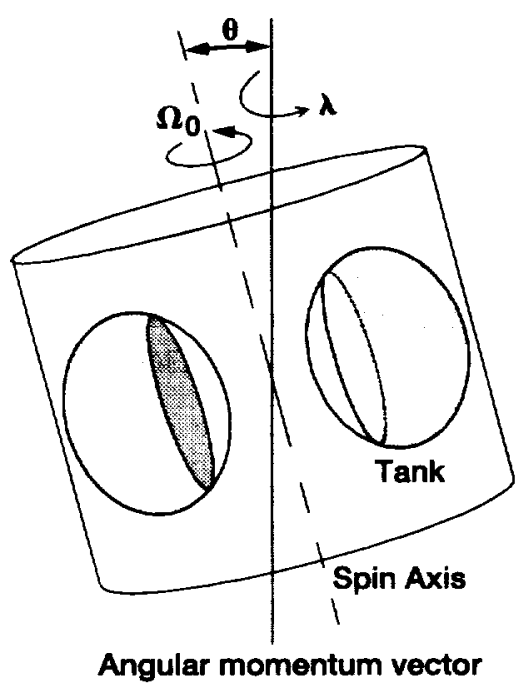

Fig. 1.-Idealized spinning spacecraft. The spin axis rotates around the angular momentum vector, setting the liquid into motion.

The angle between the spin axis and the angular momentum vector is the cone angle $\theta$, which is a measure of the magnitude of the nutation. The angular rate at which the spin axis rotates around the angular momentum vector is called the nutation frequency $\lambda$. In a body-fixed coordinate system, $\lambda$ is proportional to the spin rate $\Omega_{0}$ according to:

$$
\lambda=\Omega_{0}\left(1-\frac{I_{\text {spin }}}{I_{\text {trans }}}\right)
$$

where $I_{\text {spin }}$ is the mass moment of inertia of the spacecraft about the spin axis and $I_{\text {trans }}$ is the mass moment of inertia about a transverse axis through the center of mass. The spacecraft is assumed to be axisymmetric. Since $I_{\text {trans }}>$ $I_{\text {spin }}$ is the common mass distribution for a spinning spacecraft, Eq. (1) shows that the nutation frequency is smaller than the spin rate, $\lambda<\Omega_{0}$.
The nutation motion produces an oscillatory motion of the liquids in the tanks. This liquid motion dissipates kinetic energy at rate $E$ as a result of the viscous stresses caused by the motion. The dissipation leads to an increase in the magnitude of the coning motion [1] as shown by Eq. (2):

$$
\theta \frac{d \theta}{d t}=-\frac{\Omega_{0}^{2}\left(I_{\text {trans }}-I_{\text {spin }}\right)}{E}
$$

Since $I_{\text {trans }}>I_{\text {spin }}$, the rate of change $d \theta / d t$ of $\theta$ is positive; that is, $\theta$ increases with time. Equation (2) assumes that the liquid is merely a passive dissipator, whose motion does not affect the mass distribution (e.g., center of mass location). However, the liquid mass fraction of many spacecraft approaches 50 percent of the total mass $[2,3]$ and Eq. (2) is then a crude approximation. Furthermore, when a resonant frequency of the liquid is near the nutation frequency the dynamics of the liquid motion couples with the nutation, thereby causing the cone angle to change rapidly even in the absence of dissipation. Even if there is no dynamic coupling, the dissipation $E$ of a resonant liquid motion is extremely large, which, according to Eq. (2), will lead to a rapid increase of the cone angle. In extreme cases, the cone angle may increase so rapidly that the attitude control system cannot maintain the attitude of the spacecraft; when this occurs, the spacecraft experiences a disastrous "flat spin" [1].

For these reasons, it is important to quantify the characteristics of the liquid motions in a spinning, nutating tank. LME was designed to determine liquid resonant frequencies, and energy dissipation rate of resonant and nonresonant motions as a function of tank shape (cylinders, spheres, and propellant management devices), liquid fill level, and liquid properties.

Overview of Liquid Motions in Spinning. Nutating Tanks

Liquid in a partially-full spinning tank can oscillate in two distinctly different modes: free surface waves, and inertial (internal) waves. Of these two, the inertial wave mode is the more important because the resonant frequency of such modes are in the range that can be excited by nutation.

Free surface waves are similar to the sloshing that occurs in non-spinning tanks. In a spinning tank, the centrifugal acceleration $R_{0}\left(\Omega_{0}\right)^{2}\left(R_{0}\right.$ is the distance from the spin axis to the free surface) is analogous to a steady acceleration $g$ (such as gravity), so the resonant frequency is proportional to $\Omega_{0}(R / d)^{1 / 2}$ where $d$ is the tank diameter [4]. Since $d<R_{0}$ and the proportionality constant is greater than one, the resonant frequency is greater than the spin 
rate; in fact, unless the fill level is very small, the resonant frequency is greater than twice the spin rate [5]. Thus, the resonant frequency of free surface waves are always higher than the frequency of the nutation motion that excites them. Free surface waves cause an oscillation of the liquid center of mass, so in general both a torque and a force on the tank are produced by the waves.

Inertial waves are oscillations of the liquid interior and can occur even in the absence of a liquid free surface. The oscillations are excited by Coriolis accelerations induced by nutation of a spinning tank [6]. For a symmetrical tank spinning about its $z$-symmetry axis, the theory shows, for example, that the liquid pressure field $p(r, \theta, z) \mathrm{e}^{(-\mathrm{i} \lambda t)}$ corresponding to an oscillation frequency of $\lambda$ is governed by:

$$
\frac{\partial^{2} p}{\partial r^{2}}+\frac{\partial^{2} p}{r^{2} \partial \theta^{2}}+\left(1-\frac{4 \Omega_{0}^{2}}{\lambda^{2}}\right) \frac{\partial^{2} p}{\partial z^{2}}=0
$$

When the oscillation frequency $\lambda>2 \Omega_{0}$, this differential equation is "elliptic" and the oscillations are the free surface sloshing oscillations mentioned above. But when $\lambda<2 \Omega_{0}$, the equation is "hyperbolic" and the oscillations are inertial waves [5]. No general theory is available for the problem under discussion, but approximate analytical models indicate that even for this nonaxisymmetric geometry all the inertial wave resonances occur in the frequency range between 0 and $2 \Omega_{0}$, and the most prominent resonances have frequencies less than $\Omega_{0}$ $[7,8,9,10]$. Since the motion of the free surface is a secondary effect of an inertial wave, the liquid center of mass does not necessarily oscillate, in which case the liquid motion exerts only a torque on the tank.

The approximate analytical model used to predict the resonant frequencies for the LME tanks was based on the homogeneous vortex model of [11]. The model was exended to incorporate viscous effects was used to predict the energy dissipation rates [12]. These predictions are compared to the LME test results later in this section.

\section{Description of Liquid Motion Experiment}

\section{LME Hardware Arrangement}

The LME hardware was designed for the double adapter plate of two Shuttle middeck lockers. The experiment was actually mounted to a double adapter plate of two SpaceHab lockers, but this change in accommodations did not require any significant alteration to the hardware. The flight hardware is basically a spin table that can be made to nutate at a prescribed frequency at a fixed cone angle of about $5^{\circ}$. The test tanks are cylinders and spheres. The data acquired during a test is transmitted to the Shuttle Payload General Support Computer (PGSC), via the LME Experiment Interface Unit and the Data Acquisition System. The LME software used to control and monitor the flight tests was resident in the PGSC. Data from rotating instrumentation (e.g., load cells) are transmitted by an optical link from the spin table to the stationary hardware housing, thus eliminating the need to transmit data through slip rings. A video camera is focused on one tank to provide a visual recond of the liquid motions.

\section{Spin and Nutation Rates}

The spin rate and nutation frequency of the spin table are provided by two electric motors called the "spin" motor and the "wobble" motor. The spin motor housing in the final design was mounted on a swash-plate-like arrangement tilted at $5^{\circ}$ to the wobble motor shaft axis, and the tilt angle vector of the spin table rotated at the wobble motor rotation rate. The unsteady angular velocity $w$ and angular acceleration a of a point on the spin table, such as one of the LME tanks, is given in a coordinate system rotating with the table by:

$$
\begin{gathered}
\omega=\Omega_{\text {wobble }} \theta \sin (\lambda t+\phi) \\
\alpha=\lambda \Omega_{\text {wobble }} \theta \cos (\lambda t+\phi)
\end{gathered}
$$

where $\phi$ is a phase angle that depends on the angular location of the table point in question. For comparison, the angular velocity and acceleration of an off-axis tank in a spinning spacecraft are given by: $\omega=\lambda \theta \sin (\lambda t+\phi)$ and $\alpha=\lambda^{2} \theta \cos (\lambda t+\phi)$. Thus, if $\Omega_{\text {wobble }}=1$, the LME spin table simulates the actual motion of a spacecraft. The nutation frequency of the spin table was given by:

$$
\lambda=\boldsymbol{\Omega}_{\text {spin }}-\boldsymbol{\Omega}_{\text {wobble }}
$$

instead of $\lambda=\Omega_{\text {wobble }}$. The differences between Eqs. (4) and (5) and the analogous spacecraft relations are not critical because the liquids in the LME tanks are still subjected to a spinning, nutating motion, although the amplitude of the angular acceleration is not quite the same as for a spacecraft. Thus, the LME tests are fully capable of determining resonant frequencies and energy dissipation rates.

\section{Load Cells and Tank Support Structure}

The primary quantitative data obtained from the LME tests were the torques exerted on the test tanks by the contained liquid. These torques were measured by extremely sensitive load cells. Two load cell structures were used for each tank to provide support for the test tank and a capability of sensing both radial and tangential 
torques. The sensing element of each load cell is a set of semi-conductor strain gauges mounted to very thin stainless steel beams. The entire weight of the tank support ring structure, the test tank, and liquid is supported by the tensioned springs that connect these beams and the load cell holder brackets The plane of the sensing elements passes through the center of mass location of the tank and ring support structure. When a torque is exerted about the radial axis of the tank from the spin table axis to the tank center line, the beams of one of the two load cells deflect upward, and the beams of the other load cell deflect downward. Conversely, when a torque is exerted about the tangential axis of the tank (perpendicular to the radial axis), one end of each beam of a load cell deflects upward and the other end deflects downward, with an identical deflection pattern occurring for the beams of the other load cell. Thus, by using an appropriate electrical bridge, the load cells can measure radial and tangential torques simultaneously. (A radial torque also introduces a negligible twist to each beam.) For purely axial or radial motions of the tank without a change in the tilt of the tank, the strains imposed on the strain gauges effectively cancel out; thus, the load cells are insensitive to forces.

The beam-tensioned spring arrangement provides adequate axial support of the tank in the weightless environment of flight but not in the $1 \mathrm{~g}$ environment of a laboratory, in which the tank and support structure "sag" significantly. For that reason, the load cells could not be calibrated in the laboratory when they supported a tank. Instead, each load cell was calibrated by positioning it horizontally to eliminate the dead weight acting on the sensing elements, and a fixture was used to load the load cell statically over a range of torques. The sensitivities of a typical load cell as determined from this procedure are: $0.4 \mathrm{in}$. $-\mathrm{lb} / \mathrm{V}\left(4.52 \times 10^{5}\right.$ dyne- $\left.\mathrm{cm} / \mathrm{V}\right)$ for radial torques and $0.09 \mathrm{in}$ - $\mathrm{lb} / \mathrm{V}\left(1.02 \times 10^{5}\right.$ dyne- $\left.\mathrm{cm} / \mathrm{V}\right)$ for tangential torques. The difference between the two sensitivities is a result of the larger moment arm for radial torques compared to tangential torques. The smallest torque imposed on the load cells was $0.005 \mathrm{in}$. $-\mathrm{lb}$ ( 5600 dyne-cm). The calibrations were repeated after the flight tests. The differences in preand post-flight calibration were small, so the pre-flight calibration was used to reduce the flight data. On-Orbit just prior to a flight data test, the torque offset of each load cell was determined by rotating the spin table at the test spin rate without nutation. The measured torques (caused by slight misalignments, etc.) were subtracted electronically from the torques measured during a data test, so the recorded test torques should have been due only to the nutation motion of the tank and liquid.

\section{Test Tanks}

LME employed two generic tank shapes, a cylinder and a sphere. Figures 2 and 3 show the tank designs

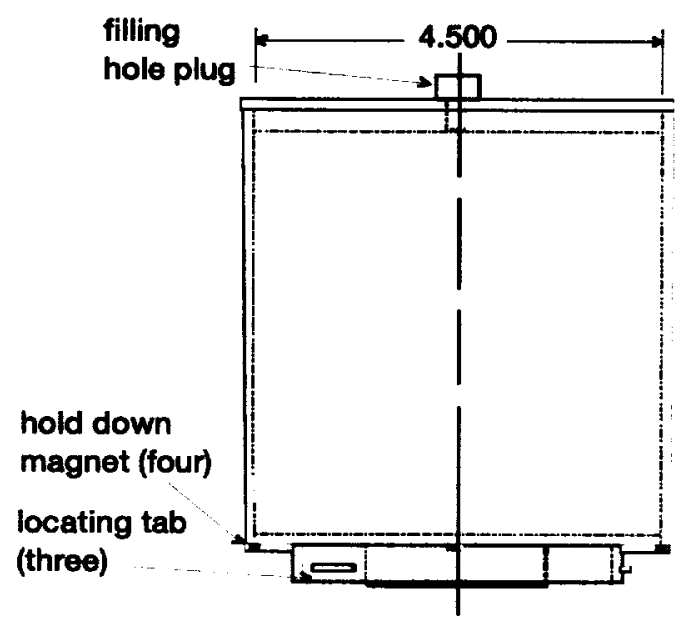

Fig. 2.-LME cylindrical tank.

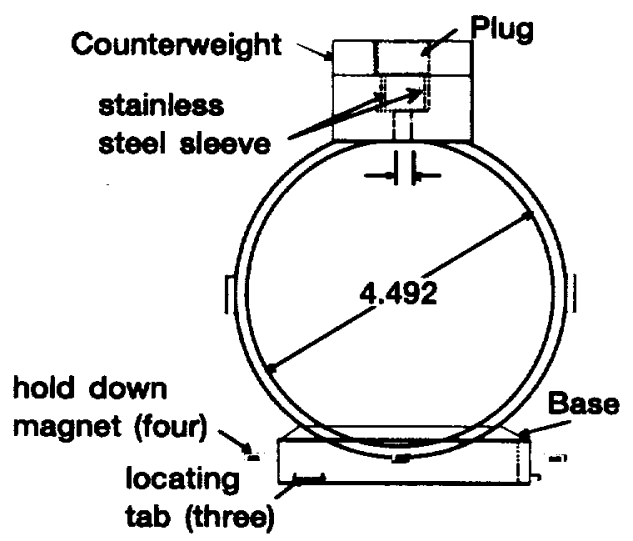

Fig. 3.-LME spherical tank.

The tanks were cast from a clear polymeric resin. Counterweights were attached to the top or bottom of each tank to make the geometric center of the tank coincide with the center of mass of the tank-structure combination.

\section{Propellant Management Devices}

In addition to "bare" spherical and cylindrical tanks, two cylindrical tanks and two spherical tanks were fitted with generic propellant management devices (PMD's). Figure 4 shows the LME PMD's. 
The cylindrical tankPMD is a circular plate containing a 2.23 in. $(5.72 \mathrm{~cm})$ diameter hole. It is located in the tank so as to bisect the tank into two equal halves. This kind of PMD has been found to damp liquid resonances [13]. The PMD was made of $1 \mathrm{~mm}$ clear polycarbonate sheet material.

The spherical tank PMD is a typical vane design. It is composed of two large circular vanes that extend over the entire tank diameter and four small vanes. In a spacecraft, the PMD captures a certain quantity of liquid between the large vanes during periods of weightlessness and directs it to the small vanes over the tank outlet. For LME, the axis of the vane system was oriented along a radial axis such that the small vanes were located at the outer diameter of the tank; this arrangement preserved the symmetry of the liquid orientation in the tank. The PMD was made of $1 \mathrm{~mm}$ clear polycarbonate sheet.
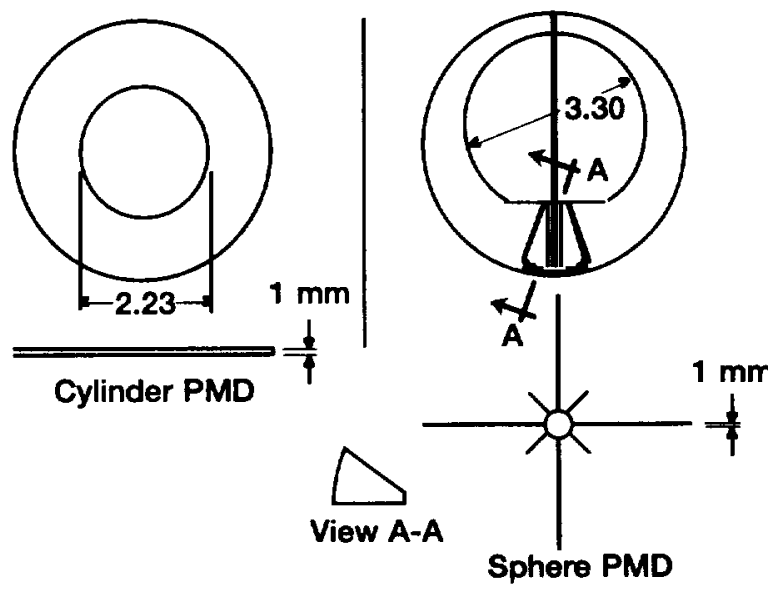

Fig. 4.-LME propellant management devices. The cylinder PMD bisects a cylindrical tank. The axis of the vaned sphere PMD is oriented along the radial axis of a spherical tank.

The cylinder PMD bisects a cylindrical tank. The axis of the vaned sphere PMD is oriented along the radial axis of a spherical tank.

\section{LME Test Matrix and Test Procedures}

\section{Tank Sets, Liquid Fill Levels, and Liquid Physical Properties}

Three sets of four tanks were used in the flight tests. Each set consisted of two cylinders and two spheres. The first two tank sets wcre composed of "bare" tanks, and the third set was two cylinders and two spheres containing PMD's. For the first tank set, called Set A, the cylinders and spheres altemated around the periphery of the spin table (i.e., cylinder, sphere, cylinder, sphere). One of each kind of tank was pre-filled to the two-thirds full level and the other was filled to the one-third level. The liquid was de-ionized water having a viscosity of $0.86 \mathrm{cp}$. One cylindrical tank was in the field of view of the video camera, so small neutrally-buoyant particles were mixed with its liquid to aid in flow visualization. The tanks also alternated around the spin table periphery for the second tank set, called Set B; for this tank set, the liquid was deionized water mixed with 55 percent glycerin (by weight) to increase the liquid viscosity to $9.5 \mathrm{cp}$. For the third tank set with the PMD's, called Set C, the two cylindrical tanks were adjacent and the two spherical tanks were adjacent. These were filled with pure de-ionized water. One cylindrical tank was pre-filled to the one-third full level and the other was filled to the two-thirds full level. The spherical tanks were also pre-filled to the one-third and two-thirds full level. The surface tension of the water was about $4 \times 10^{-4} \mathrm{lb} / \mathrm{in}$. (70 dyne/cm), and the surface tension of the water-glycerin mixture was slightly less. The density of the water was $0.036 \mathrm{lb} / \mathrm{in}^{3}\left(1.0 \mathrm{gram} / \mathrm{cm}^{3}\right)$, and that of the water-glycerin mixture was $0.041 \mathrm{lb} / \mathrm{in}^{3}{ }^{3}$ $\left(1.14 \mathrm{gram} / \mathrm{cm}^{3}\right)$. All liquid property measurements were made at $75^{\circ} \mathrm{F}\left(23.9^{\circ} \mathrm{C}\right)$.

\section{Sine Sweep and Dwell Test Characteristics}

Two general types of tests were employed, each having a specific objective. For the first type, the spin rate was held constant and the nutation frequency was varied over a range; these tests were called Sine Sweep Tests. For the second type, the spin rate and the nutation frequency were held constant for an extended period of time to obtain steady state liquid oscillations; these tests were called Sine Dwell Tests.

Sine sweep tests. -The objectives of the sine sweep tests were to determine the resonant frequencies of the liquid oscillations and the apparent viscous damping of the oscillations. At a resonance, the liquid-induced torque sensed by the load cells has a local maximum. Thus, the resonant frequencies can be determined by examining the torque time histories for maxima. The nutation frequency was changed at a rate designed to be sufficiently low such that the amplitudes of the resonant torques would be near their steady-state values; the sweep rate was small initially and increased logarithmically in time, so that most of the test time was devoted to the range $\lambda<\Omega_{\text {spin }}$ where theory indicated that prominent resonances occurred [11].

The apparent damping $g$ (fraction of critical damping) is determined by measuring the distance on the nutation frequency axis at which the torque amplitude has decayed 
to $1 / \sqrt{2}$ times the resonant peak amplitude. This damping coefficient is useful for equivalent mechanical models of an inertial wave oscillation, such as a single degree of freedom rotating, nutating disk [10].

Sine sweep tests for each tank set were conducted for three different spin rates, two (nominally $20 \mathrm{rpm}$ and $14 \mathrm{rpm}$ ) of which produced centrifugal accelerations sufficiently high to make the effects of surface tension negligible. The third spin rate (nominally $4 \mathrm{rpm}$ ) was sufficiently small such that the Bond number, defined as $B o=\rho R \Omega_{0}^{2} d / \sigma$, was of order unity, where $\rho$ is the liquid density and $\sigma$ is the liquid surface tension. For Bond numbers of unity or less, the liquid is effectively in a lowgravity environment and the interface is highly curved. Thus, the $4 \mathrm{rpm}$ spin rate tests simulated a slowly-spinning spacecraft and were meant to quantify the influence of surface tension on the resonances.

Sine dwell tests. - The objective of the sine dwell tests was to quantify the energy dissipation rates of the liquid oscillations under steady state conditions. For these tests, the spin rate and the nutation frequency were held constant for up $20 \mathrm{~min}$, to ensure that the liquid oscillations reached a steady state condition. Two sine dwell tests were conducted for each tank set.

The energy dissipation rate for each tank is computed from the measured torque amplitude and the angular velocity of the spin table at the tank location by:

$$
E_{i}=0.5\left(T_{\text {total }}-T_{\text {rigid }}\right) \omega_{i} \cos \phi_{i}
$$

Here $T_{\text {total }}$ is the amplitude of the measured sinusoidal torque, $T_{\text {rigid }}$ is the computed torque for the empty tank and tank structure, $\omega_{i}$ is the sinusoidal angular velocity of the spin table (i.e., the product $\lambda \theta$ ) and $\phi$ is the phase angle between the torque and the angular velocity sine waves; the phase angle $\phi$ is computed from the timing marks recorded in the data stream allowing for the rigid body torque. The subscript $i$ indicates a radial or tangential component of the parameter. The total energy dissipation rate is the sum of the radial and tangential dissipation rates. When the phase angle $\phi$ is between $\pm 90^{\circ}$, the energy dissipation rate is positive according to Eq. (6). This means that the liquid extracts energy from the nutation, which is eventually transformed into heat by viscous stresses (for a spacecraft, the energy is extracted from the spin kinetic energy). Conversely, when the phase angle is between $90^{\circ}$ and $270^{\circ}$, the energy dissipation rate is negative, and the liquid contributes energy to the nutation; this is unrealistic, since the liquid oscillations would then decay rather than continue in a steady state.
The rigid body torques needed for Eq. (6) are computed from the relation:

$$
T_{\text {rigid }, i}=I_{\text {trans }} \alpha_{i} \pm\left(I_{\text {spin }}-I_{\text {trans }}\right) \Omega_{0} \omega_{i}
$$

where the + sign is used if $i$ corresponds to the radial component and the - is used for the tangential component. The angular velocity and acceleration are computed from the spin motor and wobble motor rotational rates given by Eqs. (4) with $\theta \approx 5^{\circ}$ being the cone angle of the spin table.

\section{Data Analysis}

\section{Data Reduction}

Torque data were acquired for each sine sweep and sine dwell test in the form of a time histories of strain gauge voltages. The data were sampled 40 times during each spin rate period, which is more than adequate to resolve the details of the highest frequency sweep rate or spin rate used in the tests.

All the strain gauge voltages were severely contaminated by high and low frequency noise from a variety of sources including the wobble motor speed reducer. Consequently, it was necessary in the post-flight data processing to extract the true signal from each strain gauge time history by digital filtering. After filtering, the strain gauge signals were combined to compute the appropriate torques. For sine sweep tests, all data components at frequencies that were somewhat higher than the highest nutation frequency and somewhat lower than the lowest nutation frequency used in the test were filtered. For sine dwell tests, for which the frequency of the true signal did not vary with time, the filtering closely bounded the test nutation frequency. The filtering yielded good results except for the $4 \mathrm{rpm}$ spin rate tests; for these low spin rate tests, all the low frequency noise could not be completely filtered without affecting the true signal.

\section{Sine Sweep Test Results}

For a sine sweep test, the nutation frequency was varied over a prescribed range by increasing the rotation rate of the wobble motor exponentially in time from a starting value of near zero to a final value of about twice the spin motor rotation rate. As an example, Fig. 5 shows the wobble motor rotation rate history for Test A0002, for which the wobble motor rotation increased from $0.2 \mathrm{rad} / \mathrm{sec}(1.9 \mathrm{rpm})$ to $3.9 \mathrm{rad} / \mathrm{sec}(37.6 \mathrm{rpm})$. Since the nutation frequency is the difference between the spin motor and wobble motor rotation rates, the nutation frequency of this test decreased from an initial value of $18.1 \mathrm{rpm}$ to zero (when the wobble motor spin rate was $20 \mathrm{rpm}$ after about $900 \mathrm{sec}$ ), and then increased to $17.6 \mathrm{rpm}$ 


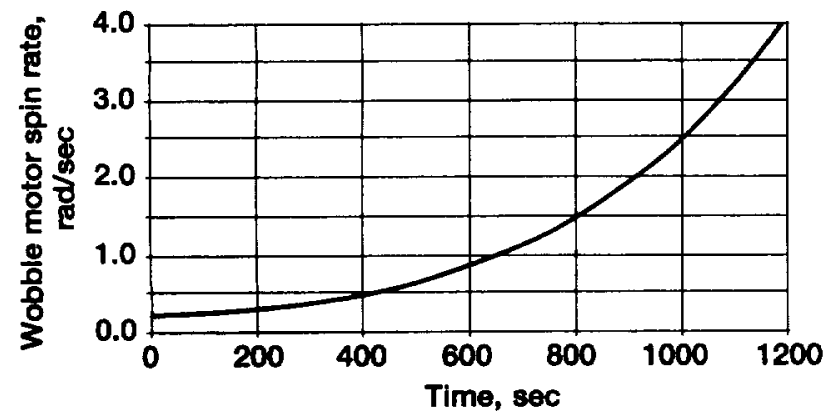

Fig. 5.-Wobble motor rotation rate for test $\mathrm{A0002}$ (20 rpm spin rate). Nutation frequency varies from $18.1 \mathrm{rpm}$ to $0 \mathrm{rpm}$ to $-17.6 \mathrm{rpm}$.

in the retrograde direction at the end of the test. The prograde motion occupied 900 of the 1200 test sec, and the retrograde motion occupied $300 \mathrm{sec}$. Consequently the sweep rate through the retrograde motion was probably too fast to excite liquid resonances.

Typical results.-Figure 6 shows a typical sine sweep test result: the radial torque amplitude history for Tank 3 of Test A0101 (2/3 full cylinder, viscosity = $1 \mathrm{cp}$, spin rate $=14.1$ spin rate) as a function of $\lambda / \Omega_{0}$. In terms of the actual test time, the start of the test corresponds to the highest value of $\lambda / \Omega_{0}$ (i.e., the right hand side of the graph) and the end of the test to the lowest (negative) value. The slight "jaggedness" of this plot is the result of several factors, including some residual noise in the data, but the primary causes are: (1) the large number of nutation cycles compressed into the graph, (2) the finite data sampling rate of the tests, which sometimes missed the peak of a cycle, and (3) the plotting software, which draws a straight line from one data point to the next without any "smoothing." Figure 6 indicates that there are two liquid resonances, one near $\lambda / \Omega_{0} \approx 0.5$ and a second near $\lambda / \Omega_{0} \approx 0.76$. (The torque peak near $\lambda \Omega_{0} \approx 0.85$ is the transient associated with the start of the test and does not indicate a liquid resonance). The normalized resonance at $\lambda \Omega_{0} \approx 0.5$ is much reduced compared to the one at $\lambda \Omega_{0} \approx 0.76$. The higher-frequency resonance $\lambda / \Omega_{0} \approx 0.76$ is concluded to be the most prominent resonance. In fact, the frequency of this resonance agrees well with the predicted resonance frequency shown previously.

The torques measured about the tangential axis also displayed resonant liquid oscillations. For example, Fig. 7 shows the tangential torque response for the same Test A0101. The resonance at $\lambda / \Omega_{0} \approx 0.76$ is apparent in Fig. 7 , which is the same value as for the radial torque in Fig. 6, but the general shape of the torque is significantly different from the radial torque. This difference was caused by the offset of the center-of-mass of the liquid along the radial axis from the center of the tank (as a result of the liquid orientation against the outer wall of the tank); this offset superimposed a nonresonant rigid-body-like torque on the resonant tangential torque that tended to hide the resonant peak. Depending on fill level, the resonant peak was,

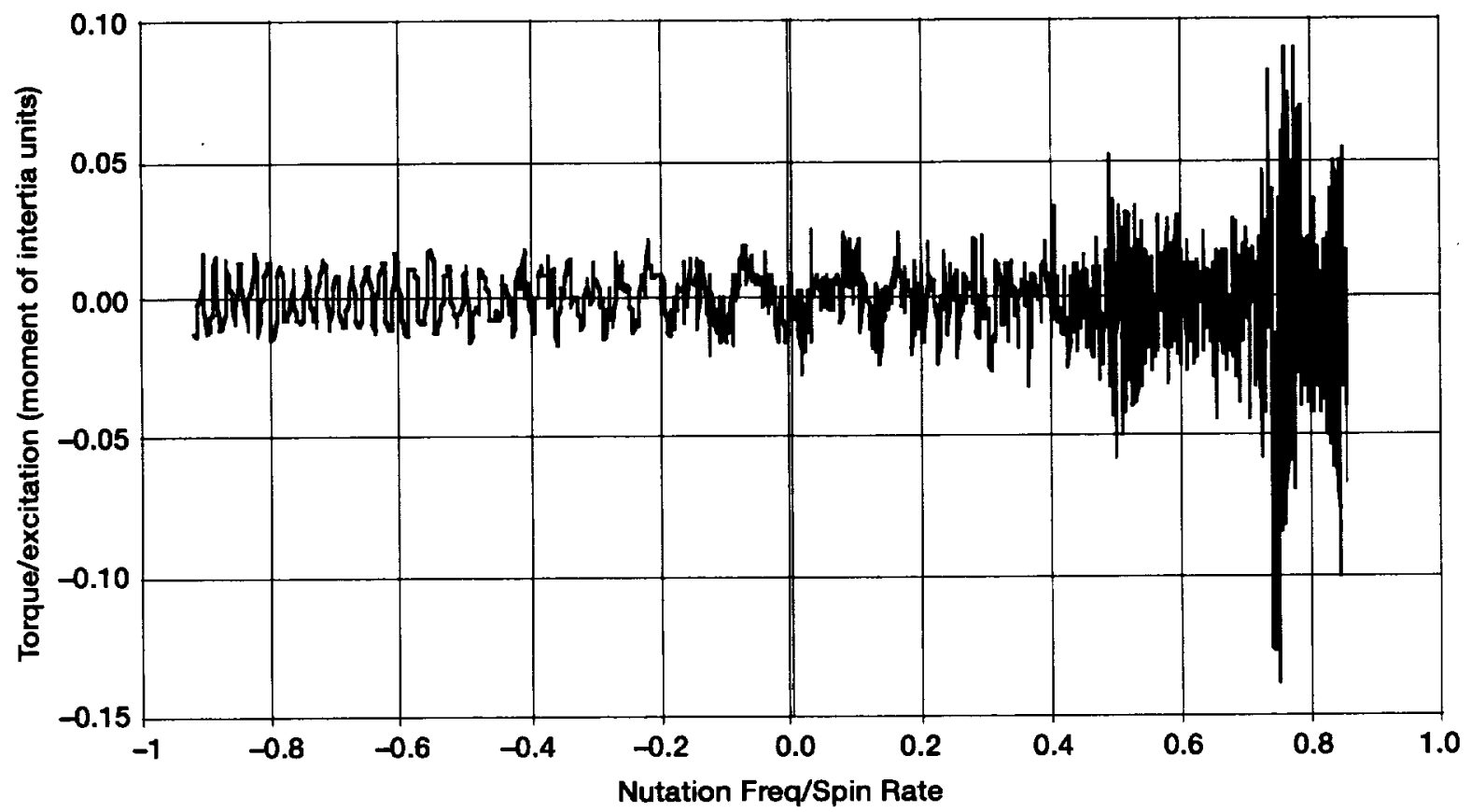

Fig. 6. - Normalized radial torque for Tank 1 (2/3 full cylinder) in Test A0101. Most prominent resonance occurs for $\lambda / \Omega_{0} \approx 0.76$. 


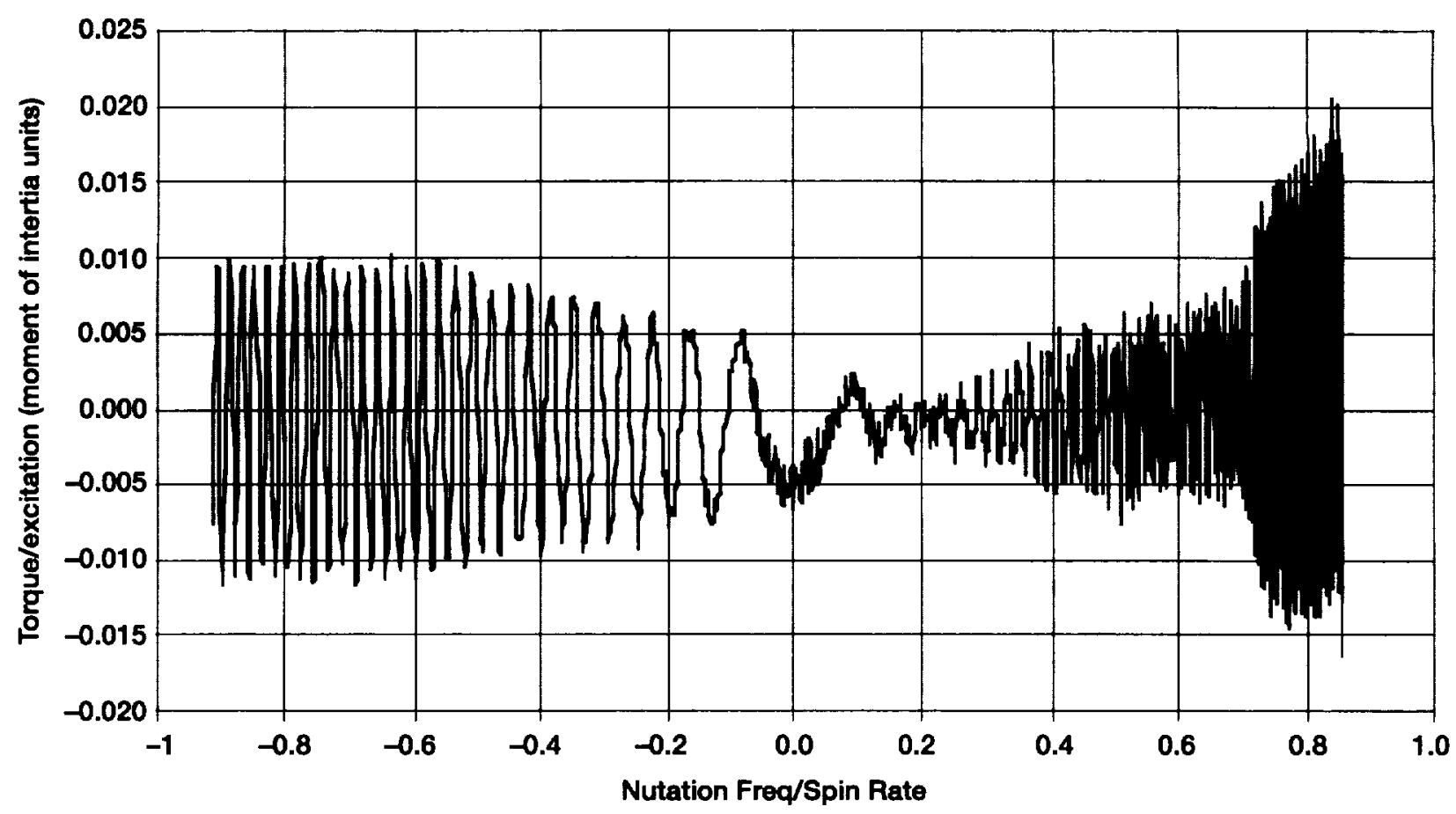

Fig. 7. - Normalized tangential torque for Tank 1 (2/3 full cylinder) in Test A0101. Torque amplitude depends on magnitude of the spin table motion.

however, sometimes more evident than in Fig. 7, but generally it was not possible to determine damping values from the tangential torque responses.

For some fill levels, the resonant frequency determined from the tangential torques was significantly less than the resonant frequency determined from the radial torques. The homogeneous vortex model is not capable of predicting these differences, since it predicts only one inertial wave resonance for a given fill level [11].The resonant damping of the liquid oscillations was computed from the radial torque responses by the half-power method. For example, from Fig. 6, the peak torque amplitude at the resonant frequency $\lambda=0.76 \Omega_{0}$ is about 0.09 , measured in momentof-inertia units. Since the tank rigid body torque is negligible compared to the liquid-induced torque, the torque amplitude at the half-power points is $0.09 / \sqrt{2}=$ 0.064 moment of inertia units. Therefore, the half-power frequency width from Fig. 6 is about $\Delta \lambda=0.03 \Omega_{0}$. The viscous damping coefficient $\mathbf{g}$ is thus computed as $\Delta \lambda 2 \lambda=0.03 \Omega_{\alpha} /\left(1.52 \Omega_{0}\right)=0.02$, or 2 percent of the critical damping. This level of damping is about the same as the free-surface sloshing damping for a tank of similar size and shape, which is reasonable since most of the energy dissipation occurs at the tank walls for either free surface sloshing or inertia waves.

D.C. offset.-Many of the measured sinusoidal torque responses showed a d.c. offset. The steady spin period, without nutation conducted before each sweep test was designed to eliminate such offsets in the recorded sweep responses (by compensating for the offset in the software), but apparently nutation introduced an additional uncompensated offset.

Summary of cylindrical tank results.-Table I summarizes the resonant frequency and damping results as determined from both the radial and tangential torque data for all the cylindrical tank tests conducted at 20 and $14 \mathrm{rpm}(\mathrm{Bo} \gg \mathrm{1})$. For some of the tests, the tangential torque resonances were not distinct enough to allow the resonant frequency or the damping to be ascertained; these cases are indicated in the table by "-.".

The radial torque resonances for the $1 / 3$ rd and $2 / 3$ full tanks occurred for nutation frequencies in the range between $0.73 \Omega_{0}$ and $0.78 \Omega_{0}$, and the tangential torque resonances occurred in the range between $0.55 \Omega_{0}$ and $0.75 \Omega_{0}$. These results are compared to the predictions of the homogeneous vortex model in Fig. 8. For the 1/3rd full tank, the model predictions compare better to the observed tangential torque resonances than to the radial torque resonances, although the predictions are good for both sets of resonances for the $2 / 3$ rd full tank. For both sets of resonances, the ratio $\lambda / \Omega_{0}$ at resonance remained nearly constant when $\Omega_{0}$ was changed from 14 to $20 \mathrm{rpm}$, which is in agreement with the model. It should be noted that even though the 
TABLE I.-SUMMARY OF RESONANT FREQUENCY $\lambda_{\text {RES }}$ AND DAMPING G DATA FOR CYLINDRICAL TANKS

\begin{tabular}{|c|c|c|c|c|c|c|c|c|c|c|}
\hline & \multirow{2}{*}{\multicolumn{2}{|c|}{ Radial torque }} & \multirow{2}{*}{\multicolumn{2}{|c|}{$\begin{array}{l}\text { Tangential } \\
\text { torque }\end{array}$}} & & & & & \multirow[b]{3}{*}{ COMMENTS } \\
\hline & & & & & & \multicolumn{2}{|c|}{ Radial torque } & \multicolumn{2}{|c|}{$\begin{array}{l}\text { Tangential } \\
\text { torque }\end{array}$} & \\
\hline TEST & $\begin{array}{l}\text { Spin rate } \\
\text { rpm }\end{array}$ & $\begin{array}{l}\lambda_{\text {res }} \\
\text { rpm }\end{array}$ & $\begin{array}{c}\gamma, \\
\text { percent }\end{array}$ & $\begin{array}{l}\lambda_{\mathrm{res}}, \\
\mathrm{rpm}\end{array}$ & $\begin{array}{c}\gamma, \\
\text { percent }\end{array}$ & $\overline{\lambda_{\text {res }},}$ & $\begin{array}{c}\gamma, \\
\text { percent }\end{array}$ & $\begin{array}{l}\lambda_{\text {res }}, \\
\text { rpm }\end{array}$ & $\begin{array}{c}\gamma, \\
\text { percent }\end{array}$ & \\
\hline & & \multicolumn{4}{|c|}{ Tank $1(\mu=1 \mathrm{cp})$} & \multicolumn{4}{|c|}{ Tank $3(\mu=10 \mathrm{cp})$} & \\
\hline $\mathbf{A 0 0 0 2}$ & 20.0 & 15.4 & 1.8 & 14.6 & - & 15.2 & 20 & 14.0 & - & $\begin{array}{l}\text { resonances are not as prominent as for } \\
14.1 \mathrm{rpm} \text { spin rate }\end{array}$ \\
\hline A0101 & 14.1 & 10.7 & 1.7 & 10.1 & - & 10.7 & 20 & 10.7 & 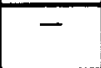 & $\begin{array}{l}\text { second smaller resonance at } \lambda=7.0 \mathrm{rpm} \\
\text { (radial and tangential) }\end{array}$ \\
\hline$\overline{B 0001}$ & 20.0 & 15.4 & - & 11.0 & $\overline{-}$ & 14.8 & $\overline{-}$ & - & $=$ & resonances amplitudes are small \\
\hline B0101 & 14.1 & 10.6 & 1.4 & 8.0 & - & 10.7 & 1.7 & 8.0 & - & several smaller resonances in radial axis \\
\hline & & \multicolumn{4}{|c|}{ Tank $1(\mu=1 \mathrm{cp})$} & \multicolumn{4}{|c|}{ Tank $2(\mu=1 \mathrm{cp})$} & \\
\hline $\mathrm{C0101}$ & 14.1 & $\begin{array}{l}10.3 \text { and } \\
10.9\end{array}$ & 27 & 10.7 & - & 10.4 & 2.4 & 10.6 & - & tanks contain a PMD \\
\hline
\end{tabular}

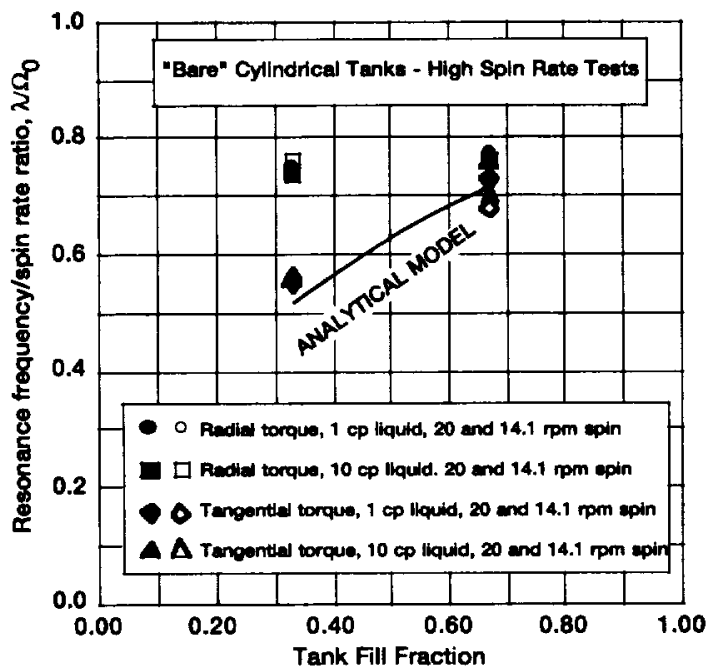

Fig. 8. - Resonant frequencies for cylindrical tanks at high spin rates.

radial torque responses occurred over a small range of $\lambda$ $\Omega_{0}$ ratios, these resonances were not an artifact or resonance of the physical setup that occurred at some definite wobble motor or spin motor speed. For each resonance the actual nutation frequencies were quite different than the wobble motor and spin motor rotation rates. The video recordings confirmed the existence of liquid resonances. During the time when the nutation frequency was sweeping through a resonance, the amplitude of the vortex-like swirling motion of the liquid oscillation increased dramatically and then decreased. None of the test results for $B o=1$ (i.e., the "low gravity" tests) showed any resonances. In fact, the actual nutation frequencies used in these tests did not exceed about $1=0.6 \Omega_{0}$, so the resonances, which are predicted to occur at $1=0.65 \Omega_{0}$ and higher (as shown by Fig. 8) would not have been excited in the tests. The video recordings did show, however, that the liquid interface was highly curved for $\mathrm{Bo}=1$, as expected.
For the bare tanks, the viscous damping coefficient $\gamma$ computed from the radial torque responses is of the order of 1 to 2 percent of critical. The damping increased with fill level and liquid viscosity, as expected. For the cylindrical tanks containing a PMD, the damping was considerably larger than for "bare" tanks. This result agrees with previous findings for a similar PMD in a cylindrical tank with hemispherical ends [13] in which resonant liquid oscillations found from drop tower tests were damped by the PMD. Furthermore, at least for the $2 / 3$ full tank, the PMD, which bisected the tank into equal halves, appeared to split the radial-axis resonance into two smaller resonances with frequencies slightly larger and slightly smaller than for the "bare" tank.

Summary of spherical tank results.-Liquid resonant oscillations were not expected to be prominent in the spherical tank sweep tests torques, since such oscillations can be excited for a spherical tank only through viscous stresses at the tank walls. Nonetheless, some resonances were observed, especially in the torque response curves for the radial axis. The resonances tended to be more highly damped than for the cylindrical tank results, and thus smaller in amplitude. The observed resonances again tended to be clustered near $\lambda=0.75 \Omega_{0}$, which in this case are 10 to 20 percent lower than the predicted values, as shown in Fig. 9. Evidently, the large viscous coupling of the liquid to the tank walls (or perhaps small nonaxisymmetric imperfections in the tanks) was sufficient to excite resonances. For the spherical tanks, there was little or no difference between the radial and tangential torque resonant frequencies. The vane-like PMDs of the spherical tanks tended to increase the radial axis liquid resonance amplitudes slightly but not the tangential axis resonances. The increased torque amplitudes were accompanied by a tendency for the damping coefficient to be decreased. 


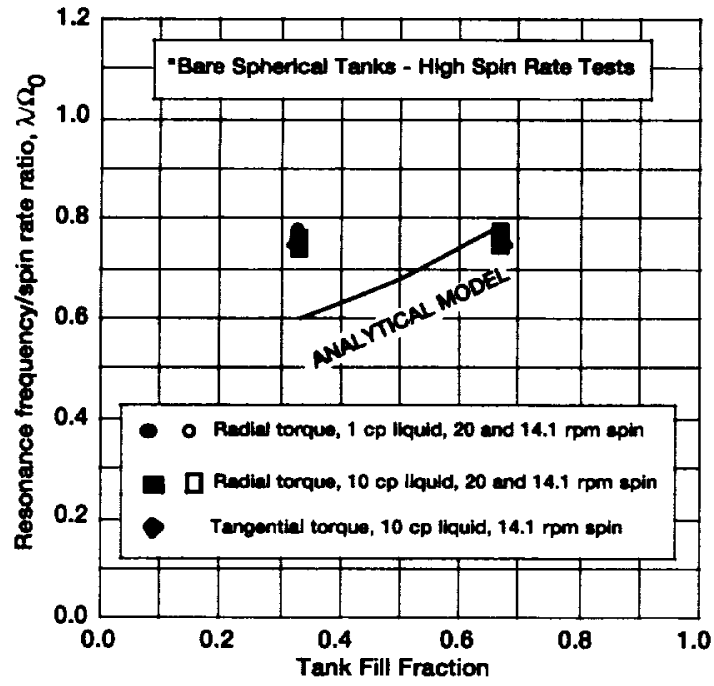

Fig. 9. - Resonant frequencies for spherical tanks at high spin rates.

Just as for the cylindrical tanks, the tests at $\mathrm{Bo}=1$ did not reveal any resonances, again for the same reasons discussed for the cylindrical tanks. The liquid interface was highly curved, as was expected. Table II summarizes all the resonant frequency and damping results for the spherical tank sweep tests conducted at 14.1 and $20 \mathrm{rpm}$.

\section{Sine Dwell Test Data}

For a sine dwell test, the filtered torque responses were all clean sine waves of constant amplitude. For that reason, typical torque plots are not shown. The rotation rates of the spin motor and the wobble motor were held constant during a sine dwell test for a per'od long enough for the liquid oscillations to achieve a steady state condition.

Cylindrical tanks.-Table III summarizes the torque and energy dissipation results for all cylindrical tanks, for spin rates of $\Omega_{0}=20$ and $14.1 \mathrm{rpm}$. Results for the "low gravity" tests $\Omega_{0} \approx 4 \mathrm{rpm}$ are not shown because the phase angle of the torque responses with respect to the tank angular velocity could not be determined reliably as a result of the noise in these data.

The torque amplitude results are reasonably consistent (i.e., they increase with spin rate and nutation rate). The computed energy dissipation rates for Tank 1 of Tank Sets $\mathrm{A}, \mathrm{B}$, and $\mathrm{C}$ are also reasonably consistent and in most cases positive, especially for the radial axis torques. However, the computed energy dissipation rates for Tank 3 of Tank Sets $A$ and $B$ are generally negative (phase angles greater than $90^{\circ}$ ), which as was discussed above is physically unrealistic. Since the energy dissipation rates are small, the phase angle between the torque and the angular velocity of the tank tended to cluster around $90^{\circ}$, so slight errors in determining the phase angle are probably responsible for the negative energy dissipation rates in many cases. However, in other cases, the phase angle is considerably larger than $90^{\circ}$. The load cell calibrations and the sign of the torque response of the load cells for Tank 3 were checked after the flight and found to be correct, so the reason why phase angles for this tank tended to be greater than $90^{\circ}$ are not apparent.

The computed negative energy dissipation rates also tended to occur more often for torque responses about the tangential axis than for the radial axis. This behavior may be related to the fact that liquid resonances found in the sine sweep tests were more prominent in the torque responses for the radial axis than for the tangential axis.

Although positive and negative energy dissipation rates also occurred for tanks containing PMD's, the PMD's tended to reduce the energy dissipation rate compared to the bare cylindrical tanks. This same trend was observed for the damping coefficient $g$ computed from the sine sweep test results. The energy dissipation data is plotted as a function of spin rate and fill level in Fig. 10.

TABLE II.-SUMMARY OF RESONANT FREQUENCY $\lambda_{\text {RES }}$ AND DAMPING G DATA FOR SPHERICAL TANKS

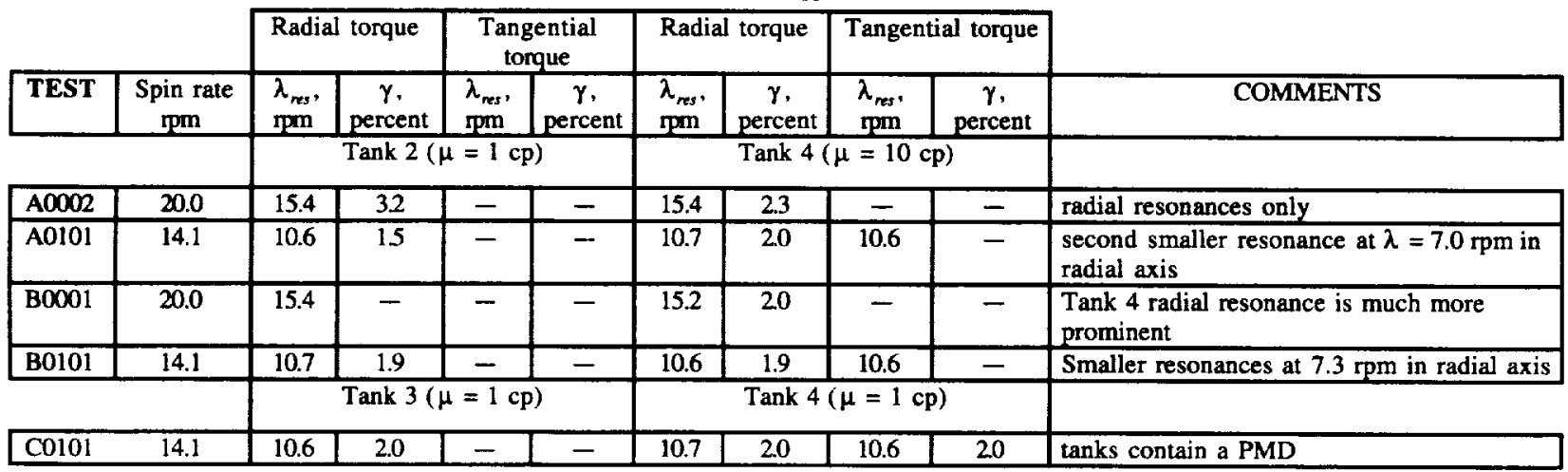


TABLE III.- SUMMARY OF ENERGY DISSIPATION RATE DATA FOR CYLINDRICAL TANKS $W=$ TANK ANGULAR VELOCITY; $T=$ NET TORQUE; $\Phi=$ PHASE ANGLE BETWEEN $T$ AND F; E - ENERGY DISSIPATION RATE

\begin{tabular}{|c|c|c|c|c|c|c|c|c|}
\hline TEST & $\begin{array}{l}\text { Spin } \\
\text { rate, } \\
\text { rpm }\end{array}$ & $\underset{\mathrm{rad} / \mathrm{sec}}{\mathrm{w}}$ & $\begin{array}{l}T_{\text {radiel }} \\
\text { in.-lb }\end{array}$ & $\begin{array}{l}\text { fadwe } \\
\text { degree }\end{array}$ & $\begin{array}{c}\mathbf{E}_{\text {redial }} \text { in.-lb/sec } \\
\text { ind }\end{array}$ & $T_{\text {ten.-lb }}$ & $\begin{array}{l}f_{\text {tangential, }} \\
\text { degree }\end{array}$ & $\begin{array}{l}\mathbf{E}_{\text {tanemtaly }} \\
\text { in.-lb/sec }\end{array}$ \\
\hline $\begin{array}{l}\text { A0301, Tank } 1 \\
\text { A0301, Tank } 3\end{array}$ & $\begin{array}{l}20 \\
20\end{array}$ & $\begin{array}{l}0.114 \\
0.114\end{array}$ & $\begin{array}{l}0.00155 \\
0.00166\end{array}$ & $\begin{array}{c}48.3 \\
102.2\end{array}$ & $\begin{array}{c}5.9 \times 10^{-5} \\
-2.0 \times 10^{-5}\end{array}$ & $\begin{array}{l}0.00903 \\
0.00213 \\
\end{array}$ & $\begin{array}{l}86.9 \\
52.1\end{array}$ & $\begin{array}{l}27 \times 10^{-6} \\
75 \times 10^{-5}\end{array}$ \\
\hline $\begin{array}{l}\text { A0401, Tank } 1 \\
\text { A0401, Tank } 3\end{array}$ & $\begin{array}{l}20 \\
20\end{array}$ & $\begin{array}{l}0.149 \\
0.149\end{array}$ & $\begin{array}{l}0.00333 \\
0.00216\end{array}$ & $\begin{array}{c}24.8 \\
128.2\end{array}$ & $\begin{array}{c}2.3 \times 10^{-4} \\
-1.0 \times 10^{4}\end{array}$ & $\begin{array}{l}0.00106 \\
0.00628 \\
\end{array}$ & $\begin{array}{l}106.9 \\
133.1\end{array}$ & $\begin{array}{l}-2.3 \times 10^{5} \\
-3.2 \times 10^{5}\end{array}$ \\
\hline $\begin{array}{l}\text { A0501, Tank } 1 \\
\text { A0501, Tank } 3\end{array}$ & $\begin{array}{l}14.1 \\
14.1 \\
\end{array}$ & $\begin{array}{l}0.056 \\
0.056\end{array}$ & $\begin{array}{l}0.00136 \\
0.00117\end{array}$ & $\begin{array}{l}45.5 \\
98.4\end{array}$ & $\begin{array}{l}2.7 \times 10^{-5} \\
-4.8 \times 10^{6} \\
\end{array}$ & $\begin{array}{l}0.00089 \\
0.00168 \\
\end{array}$ & $\begin{array}{l}95.8 \\
95.7 \\
\end{array}$ & $\begin{array}{l}-2.5 \times 10^{6} \\
-4.7 \times 10^{6}\end{array}$ \\
\hline $\begin{array}{l}\text { A0601, Tank } 1 \\
\text { A0601, Tank } 3\end{array}$ & $\begin{array}{l}14.1 \\
14.1\end{array}$ & $\begin{array}{l}0.103 \\
0.103\end{array}$ & $\begin{array}{l}0.00112 \\
0.00095\end{array}$ & $\begin{array}{c}32.0 \\
153.0\end{array}$ & $\begin{array}{r}4.9 \times 10^{-5} \\
-4.3 \times 10^{-5}\end{array}$ & $\begin{array}{l}0.00019 \\
0.00083\end{array}$ & $\begin{array}{l}139.3 \\
95.1\end{array}$ & $\begin{array}{l}-7.5 \times 10^{-6} \\
-3.8 \times 10^{6} \\
\end{array}$ \\
\hline $\begin{array}{l}\text { B0301, Tank1 } \\
\text { B0301, Tank } 3\end{array}$ & $\begin{array}{l}20 \\
20\end{array}$ & $\begin{array}{l}0.114 \\
0.114 \\
\end{array}$ & $\begin{array}{l}0.00133 \\
0.00256 \\
\end{array}$ & $\begin{array}{r}69.5 \\
159.9 \\
\end{array}$ & $\begin{array}{c}27 \times 10^{-5} \\
-1.4 \times 10^{4} \\
\end{array}$ & $\begin{array}{l}0.00212 \\
0.00254\end{array}$ & $\begin{array}{c}98.1 \\
100.5 \\
\end{array}$ & $\begin{array}{l}-1.7 \times 10^{-5} \\
-2.6 \times 10^{5}\end{array}$ \\
\hline $\begin{array}{l}\text { B0401, Tank } 1 \\
\text { B0401, Tank } 3\end{array}$ & $\begin{array}{l}20 \\
20\end{array}$ & $\begin{array}{l}0.149 \\
0.149\end{array}$ & $\begin{array}{l}0.00302 \\
0.00197\end{array}$ & $\begin{array}{c}80.9 \\
139.8\end{array}$ & $\begin{array}{c}3.8 \times 10^{-3} \\
-1.1 \times 10^{-1}\end{array}$ & $\begin{array}{l}0.00085 \\
0.00101\end{array}$ & $\begin{array}{c}95.1 \\
115.2\end{array}$ & $\begin{array}{l}-5.6 \times 10^{5} \\
-3.2 \times 10^{-5}\end{array}$ \\
\hline $\begin{array}{l}\text { B0501, Tank } 1 \\
\text { B0501, Tank } 3 \\
\end{array}$ & $\begin{array}{l}14.1 \\
14.1\end{array}$ & $\begin{array}{l}0.056 \\
0.056 \\
\end{array}$ & $\begin{array}{l}0.00073 \\
0.00053 \\
\end{array}$ & $\begin{array}{c}58.0 \\
109.3 \\
\end{array}$ & $\begin{array}{r}1.1 \times 10^{-5} \\
-4.9 \times 10^{-6}\end{array}$ & $\begin{array}{l}0.00271 \\
0.00260\end{array}$ & $\begin{array}{c}95.5 \\
103.5\end{array}$ & $\begin{array}{l}-7.3 \times 10^{6} \\
-1.7 \times 10^{5}\end{array}$ \\
\hline $\begin{array}{l}\text { B0601, Tank 1 } \\
\text { B0601, Tank } 3\end{array}$ & $\begin{array}{l}14.1 \\
14.1\end{array}$ & $\begin{array}{l}0.103 \\
0.103\end{array}$ & $\begin{array}{l}0.00113 \\
0.00046\end{array}$ & $\begin{array}{c}6.27 \\
111.4\end{array}$ & $\begin{array}{c}5.8 \times 10^{-3} \\
-8.6 \times 10^{6}\end{array}$ & $\begin{array}{l}0.00090 \\
0.00106\end{array}$ & $\begin{array}{l}106.4 \\
106.4\end{array}$ & $\begin{array}{l}-1.3 \times 10^{3} \\
-1.6 \times 10^{-5}\end{array}$ \\
\hline $\begin{array}{l}\text { C0301, Tank } 1 \\
\text { C0301, Tank } 2\end{array}$ & $\begin{array}{l}20 \\
20 \\
\end{array}$ & $\begin{array}{l}0.114 \\
0.114\end{array}$ & $\begin{array}{l}0.00027 \\
0.00101\end{array}$ & $\begin{array}{l}63.5 \\
45.6 \\
\end{array}$ & $\begin{array}{l}6.8 \times 10^{-6} \\
4.0 \times 10^{-5}\end{array}$ & $\begin{array}{l}0.00228 \\
0.00275 \\
\end{array}$ & $\begin{array}{l}56.2 \\
16.2 \\
\end{array}$ & $\begin{array}{l}7.3 \times 10^{-5} \\
1.5 \times 10^{-4} \\
\end{array}$ \\
\hline $\begin{array}{l}\text { C0401, Tank 1 } \\
\text { C0401, Tank } 2\end{array}$ & $\begin{array}{l}20 \\
20\end{array}$ & $\begin{array}{l}0.149 \\
0.149\end{array}$ & $\begin{array}{l}0.00002 \\
0.00075\end{array}$ & $\begin{array}{l}118.3 \\
107.5\end{array}$ & $\begin{array}{l}-7.4 \times 10^{7} \\
-1.7 \times 10^{5}\end{array}$ & $\begin{array}{l}0.00094 \\
0.00009\end{array}$ & $\begin{array}{l}102.8 \\
174.5\end{array}$ & $\begin{array}{l}-1.5 \times 10^{-3} \\
-6.4 \times 10^{6}\end{array}$ \\
\hline $\begin{array}{l}\text { C0501, Tank } 1 \\
\text { C0501, Tank } 2\end{array}$ & $\begin{array}{l}14.1 \\
14.1 \\
\end{array}$ & $\begin{array}{l}0.056 \\
0.056\end{array}$ & $\begin{array}{l}0.00048 \\
0.00048\end{array}$ & $\begin{array}{l}38.7 \\
85.5\end{array}$ & $\begin{array}{l}1.0 \times 10^{-5} \\
1.1 \times 10^{-6}\end{array}$ & $\begin{array}{l}0.00298 \\
0.00197 \\
\end{array}$ & $\begin{array}{l}90.5 \\
85.7\end{array}$ & $\begin{array}{r}-7.9 \times 10^{7} \\
4.2 \times 10^{-6} \\
\end{array}$ \\
\hline $\begin{array}{l}\text { C0601, Tank } 1 \\
\text { C0601, Tank } 2\end{array}$ & $\begin{array}{l}14.1 \\
14.1\end{array}$ & $\begin{array}{l}0.103 \\
0.103\end{array}$ & $\begin{array}{l}0.00071 \\
0.00042\end{array}$ & $\begin{array}{c}9.01 \\
165.6\end{array}$ & $\begin{array}{l}3.6 \times 10^{-3} \\
-2.1 \times 10^{-6}\end{array}$ & $\begin{array}{l}0.00089 \\
0.00031\end{array}$ & $\begin{array}{l}74.7 \\
79.5 \\
\end{array}$ & $\begin{array}{l}1.2 \times 10^{-5} \\
29 \times 10^{-6}\end{array}$ \\
\hline
\end{tabular}

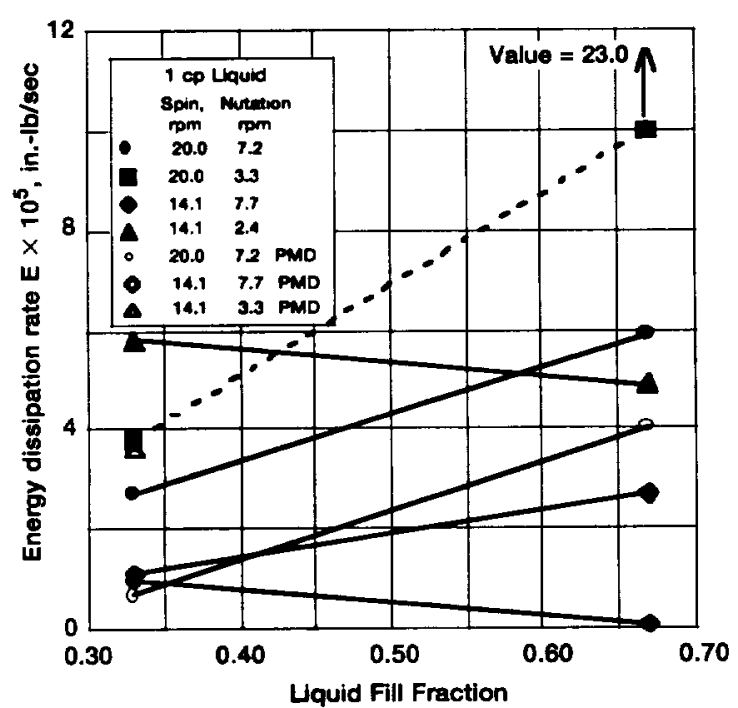

Fig. 10.-Energy dissipation rates for cylindrical tanks.

Spherical tanks.-Table IV summarizes the results for the spherical tanks, for $\Omega_{0}=20$ and $14 \mathrm{rpm}$; again, the low gravity $4 \mathrm{rpm}$ test results are not shown.

For the spherical tanks, the energy dissipation rates computed for the radial torques are nearly all positive. However, just as for the cylindrical tanks, some of the energy dissipation rate computed from the tangential axis torques are negative. Figure 11 shows the computed (positive) energy dissipation rates for the spherical tanks, for all the higher spin rate tests. The dissipation for the bare tanks tended to increase with spin rate and fill level, just as for the cylindrical tanks. For the spherical tanks with PMDs, however, the dissipation rate tended to decrease with an increase in fill level. This is probably the esult of the specific design of the vane PMD; the PMD blocked much of the vortex oscillations for the small fill level, whereas the PMD was more open with less blockage for the higher fill level. The magnitude of the dissipation rate for the spherical tanks with PMDs was sometimes larger and sometimes smaller than for the comparable bare tank.

\section{Comparison of Energy Dissipation Rates to Ground and Spacecraft Flight Results}

Many ground-test studies of energy dissipation in rotating, nutating tanks have been conducted previously at very high spin rates to minimize the effects of gravity on the liquid orientation. Most of these studies give energy dissipation correlations of the form:

$$
E=K m_{\text {liquid }} \Omega_{0}^{3} d^{2}\left(\frac{\Omega_{0}}{\lambda}\right) \theta^{2} \sqrt{\frac{\mu}{\rho \Omega_{0} d^{2}}}
$$


TABLE IV.- SUMMARY OF ENERGY DISSIPATION RATE DATA FOR SPHERICAL TANKS $\mathrm{W}=\mathrm{TANK}$ ANGULAR VELOCITY; $\mathrm{T}=$ NET TORQUE; $\Phi=$ PHASE ANGLE BETWEEN $\mathrm{T}$ AND F; E - ENERGY DISSIPATION RATE

\begin{tabular}{|c|c|c|c|c|c|c|c|c|}
\hline TEST & $\begin{array}{l}\text { Spin rate, } \\
\text { rpm }\end{array}$ & $\begin{array}{l}\mathrm{T}, \\
\mathrm{rad} / \mathrm{sec}\end{array}$ & $\begin{array}{l}T_{\text {restiel, }} \\
\text { in.-lb }\end{array}$ & $\begin{array}{l}\text { / } \\
\text { degree }\end{array}$ & $\begin{array}{c}\mathbf{E}_{\text {redilud }} \\
\text { in.-lb/sec }\end{array}$ & 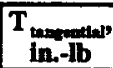 & $\begin{array}{l}\text { C tinpetals } \\
\text { degree }\end{array}$ & $\begin{array}{l}E_{\text {cuopetald }} \\
\text { in.-lb/sec }\end{array}$ \\
\hline A0301, Tank 2 & 20 & 0.114 & 0.00426 & 60.8 & $1.2 \times 10^{-4}$ & 0.00209 & 138.7 & $-9.0 \times 10^{3}$ \\
\hline A0301, Tank 4 & 20 & 0.114 & 0.00047 & 95.5 & $-2.6 \times 10^{-6}$ & 0.00117 & 135.3 & $-4.7 \times 10^{-5}$ \\
\hline $\begin{array}{l}\text { A0401, Tank } 2 \\
\text { A0401, Tank } 4\end{array}$ & $\begin{array}{l}20 \\
20\end{array}$ & $\begin{array}{l}0.149 \\
0.149\end{array}$ & $\begin{array}{l}0.00414 \\
0.00080\end{array}$ & $\begin{array}{c}6.00 \\
174.7\end{array}$ & $\begin{array}{r}3.1 \times 10^{-4} \\
-5.9 \times 10^{5}\end{array}$ & $\begin{array}{l}0.00237 \\
0.00121\end{array}$ & $\begin{array}{l}89.8 \\
85.8\end{array}$ & $\begin{array}{l}5.9 \times 10^{-7} \\
6.6 \times 10^{6}\end{array}$ \\
\hline $\begin{array}{l}\text { A0501, Tank } 2 \\
\text { A0501, Tank } 4\end{array}$ & $\begin{array}{l}14.1 \\
14.1\end{array}$ & $\begin{array}{l}0.056 \\
0.056\end{array}$ & $\begin{array}{l}0.00151 \\
0.00041\end{array}$ & $\begin{array}{l}20.9 \\
9.40\end{array}$ & $\begin{array}{l}3.9 \times 10^{-3} \\
1.1 \times 10^{-5}\end{array}$ & $\begin{array}{l}0.00101 \\
0.00081\end{array}$ & $\begin{array}{l}89.6 \\
7.2\end{array}$ & $\begin{array}{l}2.1 \times 10^{7} \\
5.1 \times 10^{-6}\end{array}$ \\
\hline $\begin{array}{l}\text { A0601, Tank } 2 \\
\text { A0601, Tank } 4\end{array}$ & $\begin{array}{l}14.1 \\
14.1\end{array}$ & $\begin{array}{l}0.103 \\
0.103\end{array}$ & $\begin{array}{l}0.00287 \\
0.00090\end{array}$ & $\begin{array}{l}15.7 \\
22.0\end{array}$ & $\begin{array}{l}1.4 \times 10^{-4} \\
4.3 \times 10^{-5}\end{array}$ & $\begin{array}{l}0.00132 \\
0.00090\end{array}$ & $\begin{array}{l}96.9 \\
93.2\end{array}$ & $\begin{array}{l}-8.2 \times 10^{-6} \\
-2.6 \times 10^{-6}\end{array}$ \\
\hline $\begin{array}{l}\text { B0301, Tank2 } \\
\text { B0301, Tank } 4\end{array}$ & $\begin{array}{l}20 \\
20\end{array}$ & $\begin{array}{l}0.114 \\
0.114\end{array}$ & $\begin{array}{l}0.00246 \\
0.00061\end{array}$ & $\begin{array}{l}25.5 \\
63.9\end{array}$ & $\begin{array}{l}1.3 \times 10^{-4} \\
1.5 \times 10^{-5}\end{array}$ & $\begin{array}{l}0.00202 \\
0.00151\end{array}$ & $\begin{array}{l}97.5 \\
82.6\end{array}$ & $\begin{array}{c}-1.5 \times 10^{3} \\
1.1 \times 10^{-5}\end{array}$ \\
\hline $\begin{array}{l}\text { B0401, Tank } 2 \\
\text { B0401, Tank } 4\end{array}$ & $\begin{array}{l}20 \\
20\end{array}$ & $\begin{array}{l}0.149 \\
0.149\end{array}$ & $\begin{array}{l}0.00356 \\
0.00086\end{array}$ & $\begin{array}{l}122 \\
50.6\end{array}$ & $\begin{array}{l}2.6 \times 10^{-4} \\
4.1 \times 10^{-5}\end{array}$ & $\begin{array}{l}0.00217 \\
0.00149\end{array}$ & $\begin{array}{l}90.8 \\
79.3\end{array}$ & $\begin{array}{c}-2.8 \times 10^{-6} \\
2.1 \times 10^{-5}\end{array}$ \\
\hline $\begin{array}{l}\text { B0501, Tank } 2 \\
\text { B0501, Tank } 4\end{array}$ & $\begin{array}{l}14.1 \\
14.1\end{array}$ & $\begin{array}{l}0.056 \\
0.056\end{array}$ & $\begin{array}{l}0.00033 \\
0.00310\end{array}$ & $\begin{array}{l}37.5 \\
39.1\end{array}$ & $\begin{array}{l}7.4 \times 10^{6} \\
6.8 \times 10^{-5}\end{array}$ & $\begin{array}{l}0.00149 \\
0.00105\end{array}$ & $\begin{array}{l}75.9 \\
91.9\end{array}$ & $\begin{array}{c}1.0 \times 10^{-3} \\
-9.9 \times 10^{7}\end{array}$ \\
\hline $\begin{array}{l}\text { B0601, Tank } 2 \\
\text { B0601, Tank } 4\end{array}$ & $\begin{array}{l}14.1 \\
14.1\end{array}$ & $\begin{array}{l}0.103 \\
0.103\end{array}$ & $\begin{array}{l}0.00198 \\
0.00060\end{array}$ & $\begin{array}{l}5.08 \\
15.5\end{array}$ & $\begin{array}{l}1.0 \times 10^{-4} \\
3.0 \times 10^{-5}\end{array}$ & $\begin{array}{l}0.00132 \\
0.00105\end{array}$ & $\begin{array}{l}88.2 \\
86.9\end{array}$ & $\begin{array}{l}2.1 \times 10^{-6} \\
2.9 \times 10^{-6}\end{array}$ \\
\hline $\begin{array}{l}\text { C0301, Tank } 3 \\
\text { C0301, Tank } 4\end{array}$ & $\begin{array}{l}20 \\
20\end{array}$ & $\begin{array}{l}0.114 \\
0.114\end{array}$ & $\begin{array}{l}0.00458 \\
0.00118\end{array}$ & $\begin{array}{l}73.5 \\
75.2\end{array}$ & $\begin{array}{l}7.4 \times 10^{-3} \\
1.7 \times 10^{-5}\end{array}$ & $\begin{array}{l}0.00103 \\
0.00089\end{array}$ & $\begin{array}{l}131.9 \\
119.7\end{array}$ & $\begin{array}{l}-3.9 \times 10^{3} \\
-2.5 \times 10^{5}\end{array}$ \\
\hline $\begin{array}{l}\text { C0401, Tank } 3 \\
\text { C0401, Tank } 4\end{array}$ & $\begin{array}{l}20 \\
20\end{array}$ & $\begin{array}{l}0.149 \\
0.149\end{array}$ & $\begin{array}{l}0.00560 \\
0.00144\end{array}$ & $\begin{array}{l}37.6 \\
35.7\end{array}$ & $\begin{array}{l}3.3 \times 10^{-4} \\
8.7 \times 10^{-5}\end{array}$ & $\begin{array}{l}0.00236 \\
0.00084\end{array}$ & $\begin{array}{l}101.7 \\
81.1\end{array}$ & $\begin{array}{c}-3.6 \times 10^{3} \\
9.6 \times 10^{-6}\end{array}$ \\
\hline $\begin{array}{l}\text { C0501, Tank } 3 \\
\text { C0501, Tank } 4\end{array}$ & $\begin{array}{l}14.1 \\
14.1\end{array}$ & $\begin{array}{l}0.056 \\
0.056\end{array}$ & $\begin{array}{l}0.00201 \\
0.00042\end{array}$ & $\begin{array}{l}38.9 \\
84.2\end{array}$ & $\begin{array}{l}4.4 \times 10^{-5} \\
1.2 \times 10^{-6}\end{array}$ & $\begin{array}{l}0.00169 \\
0.00064\end{array}$ & $\begin{array}{l}97.3 \\
85.5\end{array}$ & $\begin{array}{c}-6.0 \times 10^{6} \\
1.4 \times 10^{-6}\end{array}$ \\
\hline $\begin{array}{l}\text { C0601, Tank } 3 \\
\text { C0601, Tank } 4\end{array}$ & $\begin{array}{l}14.1 \\
14.1\end{array}$ & $\begin{array}{l}0.103 \\
0.103\end{array}$ & $\begin{array}{l}0.00187 \\
0.00022\end{array}$ & $\begin{array}{l}25.3 \\
7.1\end{array}$ & $\begin{array}{l}8.7 \times 10^{-5} \\
2.5 \times 10^{-6}\end{array}$ & $\begin{array}{l}0.00145 \\
0.00050\end{array}$ & $\begin{array}{l}91.1 \\
98.6\end{array}$ & $\begin{array}{l}-1.5 \times 10^{6} \\
-3.9 \times 10^{6}\end{array}$ \\
\hline
\end{tabular}

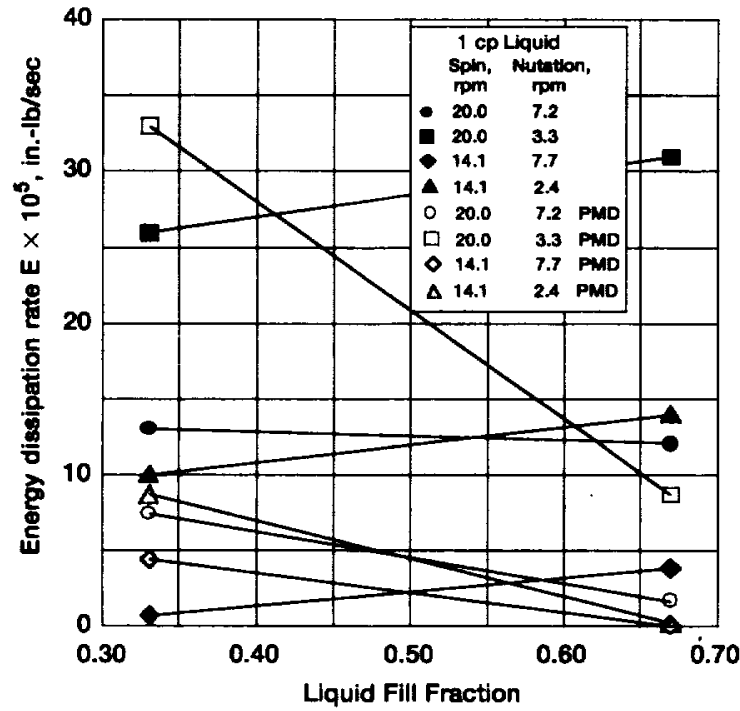

Fig. 11.-Energy dissipation rates for spherical tanks.

where $K$ is proportionality constant of order unity that depends on the spacecraft-tank geometry, $\mu$ is the liquid viscosity, $\rho$ is the liquid density, $d$ is the tank diameter, and $\theta$ is the cone angle [14]. The dependency of $E$ on $\theta^{2}$ follows from Eq. (2). For comparison to this ground-test correlation, a typical LME case is: $2 / 3$ full spherical tank. Assuming $K \approx 1$, Eq. (8) predicts that the LME energy dissipation rate is $E=0.00014 \mathrm{in}$.-lb/sec. The LME parameters correspond to Test A0401, Tank 1, for which the measured energy dissipation rate, as shown in Table IV is about $0.00023 \mathrm{in}-\mathrm{lb} / \mathrm{sec}$. The predicted and measured values of $E$ are reasonably close considering that the value of $K$ in Eq. (8) is not known for the LME geometry and that the correlation is based on data that contains a large amount of scatter.

Both Eq. (8) and the LME data plotted in Figs. 10 and 11 agree in the trend that the energy dissipation rate increased with an increase in spin rate or fill level and decreased with an increase in nutation frequency.

Nonproprietary data from flight tests of actual spinning spacecraft are difficult to find. However, comparisons of Eq. (8) to a considerable number of flight tests for "anonymous" spacecraft have been made previously [15]. It was found that the ratio of the dissipation rate measured in flight to that predicted from Eq. (8) varied from about 0.3 to about 6 . The ratios of the various LME test data to Eq. (8) vary in the range of 0.3 to 0.5 . Consequently, it can be concluded that the LME test results compare with and predict the available flight test data reasonably well.

\section{$\underline{\text { Summary }}$}

The Liquid Motion Experiment has provided valuable data on the interaction between spinning liquids and tanks in low gravity. Forces which are not measurable on the 
ground due to the masking effects of gravity have been measured on LME. Liquidresonant frequencies and viscous damping coefficients were determined by sine sweep tests. The observed resonance frequencies for cylindrical tanks depended on fill level and were in the range of 0.73 to 0.78 times the spin rate for resonances about the radial axis and in the range of 0.55 to 75 times the spin rate for resonances about the tangential axis. The available analytical model predicts only one resonance for a given fill level, and this prediction agreed rather closely with the tangential axis resonance frequencies observed in the tests. The resonances for spherical tanks were in the range of 0.74 to 77 times the spin rate and did not vary significantly between the tangential and radial axes. Energy dissipation rates were determined by sine dwell tests. The LME energy dissipation rates varied from 0.3 to 0.5 times the estimates obtained from previous ground tests and spacecraft flight data. LME has both broadened and deepened our understanding of how liquid oscillations interact with spinning spacecraft, and will lead directly to improved spacecraft design. The LME results also point out the need for improved analytical models of such liquid oscillations. Areas for further work with LME could include testing of specific spacecraft designs and tanks whose centerline is on the spin axis.

\section{$\underline{\text { References }}$}

1. Thomson, W.T, "Introduction to Space Dynamics," John Wiley \& Sons, New York, 1961.

2. Agrawal, B.N. "Attitude Stability of Aysmmetric Dual-Spin Spacecraft with Large Liquid Fraction" AIAA Paper 90-3491-CP, 1990.

3. Agrawal, B.N., "An Overview of INTELSAT Activities on Liquid Slosh," Dynamic Behavior of Liquids on Spacecraft Attitude Control, Proc. $1^{\text {st }}$ INTELSAT/ESA Symposium, Washington, D.C., 1984.
4. Abramson, H.N., "The Dynamic Behavior of Liquids in Moving Containers," NASA SP-106, 1966.

5. Weihs, D. and Dodge, F.T., "Liquid Motions in Nonaxisymmetric, Partially Filled Containers Rotating at Zero Gravity," AIAA J. of Spacecraft and Rockets, 28, pp. 425-432, 1991.

6. Greenspan, H.P., The Theory of Rotating Fluids, Cambridge University Press, 1969.

7. Pfeiffer, F., "Ein Naherungsverfahren fur Flussigkeitgefullte Kreisel," Ingenieur-Archiv, 43, pp. 306-316, 1974.

8. El-Rahab, M. and Wagner P., "Vibration of a Liquid with a Free Surface in a Spinning Spherical Tank," J. Sound and Vibration, 76, pp. 83-93, 1974.

9. Agrawal, B. N., "Dynamic Characteristics of Liquid Motion in Partially Filled Tanks of a Spinning Spacecraft," AIAA J. Guidance and Control, 16, pp. 636-640, 1993.

10. Dodge, F.T., Unruh, J.F., Green, S.T., and Cruse, M.W.,"A Mechanical Model of Liquid Inertial Waves for Use with Spinning Spacecraft," Fluid Transients 1994, ASME, New York, 1994.

11. Dodge, F.T., Cutshall, W.K., Green, S.T., and Unruh, J.F., "Modeling Low-G Motions in Spacecraft Tanks," Final Report, Southwest Research Institute IR\&D Project 04-9769, 1996.

12. Dodge, F.T., Green, S.T., and Unruh, J.F., "Modeling Liquid Motions in Spinning Spacecraft Tanks," Final Report (in preparation), Southwest Research Institute IR\&D Project 04-9946, 1998.

13. Pocha, J.J., "An Experimental Investigation of Spacecraft Sloshing," Space Communication and Broadcasting, 5, pp. 323-332, 1987.

14. Vanyo,J.P., 1973, "An Energy Assessment for Liquids in a Filled Precessing Cavity", ASME J. Applied Mechanics, 40, pp. 851-856.

15. Dodge,F.T., 1982,"Energy Dissipation in the GSTAR/ Spacenet Liquid Propellant Tanks," Final Report, SwRI Project 06-6771-111. 
Public reporting bunden for this collection of information is estimated to average 1 hour per response, including the time for reviewing instructions, searching existing data sources, gathering and maintaining the data needed, and completing and reviewing the collection of information. Send comments regarding this burden estimate or any other aspect of this collection of information, including suggestions for reducing this burden, to Washington Headquarters Services, Directorate for Information Operations and Reports, 1215 Jefferson Davis Highway, Suite 1204, Arlington, VA 22202-4302, and to the Office of Management and Budget, Papenwork Reduction Project (0704-0188), Washington, DC 20503.

\begin{tabular}{|l|c|c|}
\hline 1. AGENCY USE ONLY (Leave blank) & $\begin{array}{c}\text { 2. REPOFT DATE } \\
\text { July } 1998\end{array}$ & $\begin{array}{c}\text { 3. REPOFT TYPE AND DATES COVERED } \\
\text { Technical Memorandum }\end{array}$ \\
\hline
\end{tabular}

4. TITLE AND SUBTTILE

5. FUNDING NUMBERS

Liquid Motion Experiment Flight Test Results

6. AUTHOR(S)

WU-632-1A-1X-00

David J. Chato, Penni J. Dalton, Franklin T. Dodge and Steve Green

7. PERFoRMING ORGANZATION NAME(S) AND ADDRESS(ES)

National Aeronautics and Space Administration

Lewis Research Center

Cleveland, Ohio 44135-3191

\section{SPONSORINGMONITORING AGENCY NAME(S) AND ADDRESS(ES)}

National Aeronautics and Space Administration

Washington, DC 20546-0001
8. PERFORMING ORGANIZATION REPORT NUMBER

E-11252

10. SPONSORINCMONITORING AGENCY REPORT NUMBER

NASA TM-1998-208479

AIAA-98-3197

\section{SUPPLEMENTARY NOTES}

Prepared for the 34th Joint Propulsion Conference cosponsored by AIAA, ASME, SAE, and ASEE, Cleveland, Ohio, July 12-15, 1998. David J. Chato and Penni J. Dalton, NASA Lewis Research Center; Franklin T. Dodge and Steve Green, South West Research Institute, 6220 Culebra Road, San Antonio, Texas 78228-0510. Responsible person, David J. Chato, organization code 5870, (216) 977-7488.

12a. DISTRIBUTIONAYAILABILITY STATEMENT 12b. DISTRIBUTION CODE

Unclassified - Unlimited

Subject Category: 34

Distribution: Nonstandard

This publication is available from the NASA Center for AeroSpace Information, (301) 621-0390.

13. ABSTRACT (Maximum 200 words)

The Liquid Motion Experiment (LME), designed to study the effects of liquid motion in rotating tanks, was flown on STS 84. LME was essentially a spin table that created a realistic nutation motion of scale-model tanks containing liquid. Two spherical and two cylindrical transparent tanks were tested simultaneously, and three sets of such tanks were employed to vary liquid viscosity, fill level, and propellant management device (PMD) design. All the tanks were approximately 4.5 inches diameter. The primary test measurements were the radial and tangential torques exerted on the tanks by the liquid. Resonant frequencies and damping of the liquid oscillations were determined by sine sweep tests. For a given tank shape, the resonant frequency depended on fill level. For the cylindrical tanks, the resonances had somewhat different frequencies for the tangential axis $(0.55$ to 0.75 times spin rate $)$ and the radial axis ( 0.73 to 0.78 times spin rate), and the tangential axis resonance agreed more closely with available analytical models. For the spherical tanks, the resonant frequencies were between 0.74 to 0.77 times the spin rate and were the same for the tangential and radial axes. The damping coefficients varied from about $1 \%$ to $3 \%$ of critical, depending on tank shape, fill level, and liquid viscosity. The viscous energy dissipation rates of the liquid oscillations were determined from sine dwell tests. The LME energy dissipation rates varied from 0.3 to 0.5 times the estimates obtained from scaling previous ground tests and spacecraft flight data. The PMDs sometimes enhanced the resonances and energy dissipation rates and sometimes decreased them, which points out the need to understand better the effects of PMD on liquid motion as a function of PMD and tank design.

\section{SUBJECT TERMS}

Microgravity; Fluid management; Spin stabilization

15. NUMBER OF PAGES

19

16. PRICE CODE

\begin{tabular}{|c|c|}
\hline $\begin{array}{c}\text { 17. SECURTY CLASSIFICATION } \\
\text { OF REPORT } \\
\text { Unclassified }\end{array}$ & $\begin{array}{c}\text { 18. SECURITY CLASSIFICATION } \\
\text { OF THIS PAGE } \\
\text { Unclassified }\end{array}$ \\
\hline
\end{tabular}

NSN 7540-01-280-5500

19. SECURITY CLASSIFICATION OF ABSTRACT

Unclassified
$\mathrm{A03}$

20. LIMITATION OF ABSTRACT 